\title{
Dialectics and the Sublime in Evelyn Underhill's Mysticism: The Nature and Development of Spiritual Consciousness (PhD Abstract, 2014)
}

\author{
PETER CHONG-BENG GAN \\ Monash University, Malaysia
}

Published online: 15 October 2016

This study is an attempt to read Evelyn Underhill's Mysticism: The Nature and Development of Spiritual Consciousness, her premier work on mysticism, through the hermeneutical lens of dialecticism and sublimity. The book constitutes a documentation of Underhill's extensive investigation into the field of mysticism with a prominent attention given to Christian mysticism. By combining a reliance upon the testimonies of Christian mystics and the philosophical meditations of some eminent thinkers, with a definition of mysticism as fundamentally a profound relationship between the self and God as infinite reality, Underhill deftly constructs a theoretical edifice that preserves the distinctiveness of Christian mysticism while appealing to the rational sensibilities of those seeking a more non-sectarian, universal mysticism. Notwithstanding the developed and variegated intellectual histories of the concepts of the dialectic and the sublime, I have selected the dialectics of Hegel, and Kant's aesthetic theory of the sublime as most suitably capable of illuminating the many valuable features significant to mysticism as well as addressing two important questions that arise from some of these features. One question concerns the nature of apparently contradictory statements in the writings of mystics, and another is connected to the uniqueness of mystical experiences. While the theme of dialecticism helps with responding to the former question, plausible answers to the latter question are derivable from a comparative analysis of mystical and sublime experiences as analogues. A salient component of Underhill's Mysticism is her detailed exposition of the stages of mystical development as gleaned through her familiarity with the vast collection of mystical literature. My study is divided into two main divisions. The first division consists primarily of an endeavour to delineate a metaphysical structure that underpins the general notion of mystical relationship as a transformative one between the finite self and infinite being. The second division delves into discussions revolving around relevant ideas that pervade each of the five stages of mystical development. Throughout these divisions, the frames of Hegel's dialectics and Kant's theory of the sublime will be applied to areas amenable to such interpretive analysis. It is the hope of this research that, from it, some enlargement of scholarship in mysticism in general as 
well as Underhill studies in particular will ensue. Moreover, from a discourse that engages mysticism, dialecticism, and sublimity, a greater appreciation of the apparently paradoxical mystical vocabulary that seemingly lacks rational justification can possibly emerge. A strange harmony lurks between that which is open to rationalisation and that which hides from the peering gaze of reason. Is it any wonder that the more a mystic complains about the ineffability of her experience the more she writes about it? 